\title{
Adaptation of the Growth Hormone and Insulin-like Growth Factor-I Axis to Chronic and Severe Calorie or Protein Malnutrition
}

\author{
Michelle H. Oster, * Paul J. Fielder, ${ }^{*}$ Nancy Levin, * and Michael J. Cronin * \\ *Endocrine Research Department, and ${ }^{\ddagger}$ Cell Biology and Metabolism Department, Genentech, Inc., South San Francisco, \\ California 94080
}

\begin{abstract}
The hierarchy of diet components (e.g., protein, carbohydrate, vitamins, and minerals) influencing growth hormone (GH), insulin-like growth factor-I (IGF-I), and their binding proteins (BP) is not well defined. Young adult rats were fed diets for $1 \mathrm{mo}$ that included low protein or $60 \%$ and $40 \%$ of carbohydrate calories. We hypothesized that levels of both hormones, their dominant BPs and liver IGF-I mRNA would fall, and that part of the mechanism for decreasing serum IGF-I would be enhanced IGFBP-3 protease activity. By day 30, caloric deprivation to $40 \%$ lowered serum GH, GHBP, IGF-I and IGFBP-3, and liver IGF-I mRNA. This was the only condition resulting in body weight loss $(-15 \%)$ vs $39 \%$ gain in controls. Restriction to $60 \%$ calories had no impact on BP levels, slightly lowered IGFI (-12\%) in the face of a $95 \%$ inhibition of GH levels, while allowing a modest $9 \%$ body weight gain. Protein deprivation lowered serum GH, IGF-I and IGFBP-3, and liver IGF-I mRNA, while GHBP levels were normal. The reduced total IGF-I under these dietary conditions could not be explained by an increase in IGFBP-3 protease activity, or a decrease in the association of IGF-I with IGFBP-3 and the acid labile subunit. (J. Clin. Invest. 1995. 95:2258-2265.) Key words: binding proteins - growth hormone - insulin-like growth factor-I • malnutrition
\end{abstract}

\section{Introduction}

Nutritional status is a comorbidity variable in a multitude of diseases (e.g., AIDS, cancer) and time to death is predicted by the magnitude of body cell mass depletion $(1,2)$. The anabolic growth hormone (GH) 1 /insulin-like growth factor I (IGF-I) axis, including a host of circulating binding proteins (BP), is a complex endocrine system that promotes statural growth during development and directs substrate availability toward lean body mass vs fat throughout the lifespan. Pituitary-derived GH stimulates IGF-I synthesis and export from the liver, the primary

Address correspondence to Michelle H. Oster, Genentech, Inc., MS 37, 460 Point San Bruno Boulevard, South San Francisco, CA 94080. Phone: 415-225-6463; FAX: 415-225-6497.

Received for publication 25 October 1994 and in revised form 12 December 1994.

1. Abbreviations used in this paper: $\mathrm{BP}$, binding protein; GH, growth hormone; IGF-I, insulin like growth factor-I; LoPro, low protein diet.

J. Clin. Invest.

(c) The American Society for Clinical Investigation, Inc.

0021-9738/95/05/2258/08 \$2.00

Volume 95, May 1995, 2258-2265 source of circulating IGF-I; this coupling of GH to IGF-I production appears optimal only with adequate dietary intake and general health (3). Insulin-like growth factor-I, in turn, targets a wide variety of cells, where it stimulates multiple cellular responses, including glucose and amino acid uptake as well as synthesis of DNA, RNA, and cellular protein (reviewed in reference 4).

Given this understanding of the system biology, the GH/ IGF-I axis must sense and adjust to reductions in essential nutrient availability. Indeed, a generation ago Grant et al. (5), and Hintz et al. (6) first observed that serum IGF bioactivity was decreased in protein-malnourished children. Soliman et al. (7) later reported low serum IGF-I bioactivity and high serum GH levels in children with combined protein, energy, and micronutrient deficits; these hormones returned to normal after nutritional rehabilitation (7).

Since these studies, an effort to understand the metabolic and nutrient controls of the GH/IGF-I axis has evolved (3). In animal models, a spectrum of micronutrient (e.g., potassium [8], magnesium [9], zinc [9, 10]) and macronutrient (carbohydrate $[11,12]$, protein $[6,7,13-22]$, fat [23]) deficiencies have produced variable $\mathrm{GH}$ responses, with no change or decreased liver GH-binding and consistently diminished serum IGF-I and IGFBP-3 levels. While these studies describe nutritional influences on the axis, most were limited to pubertal animals studied for a few days and did not control for equivalent micronutrient intake when deficient macronutrient diets were prepared. One report demonstrates that protein deficiency in the weanling rat reduces serum IGF-I significantly more than in the adult rat (24). This suggests a reduction in IGF-I sensitivity to protein deficiency with age.

Under normal conditions both GH and IGF-I are associated with specific BPs in the circulation; the plurality of GH is bound to a high affinity GHBP, and the majority of IGF-I is bound in a 150-kD complex consisting of IGF-I, IGFBP-3, and an acidlabile subunit (84-86 $\mathrm{kD}$ ). The remaining IGF-I is either free $(<5 \%)$ or bound to five other IGFBPs in binary complexes. Free GH and IGF-I are considered to be the active forms of the hormones. The effects of restricted protein and energy intake on GHBP are unknown. In contrast, protein restriction was reported to decrease serum IGFBP-3 in pubertal, 4-wk-old rats (19). This was speculated to occur due to diminished IGFBP3 protein production or stability, perhaps via IGFBP-3 proteolysis, an activity correlated with severe catabolic conditions and late pregnancy (25-28). The influence of malnutrition alone (in the absence of trauma) on this protease or the state of the $150-\mathrm{kD}$ heterotrimer is unknown.

The purpose of these experiments was to define in young adult rats the response of the GH/IGF-I axis during the progressive metabolic adaptation to discrete and chronic protein or energy deficiency. The primary postulate was that these dietary restrictions would dramatically suppress serum IGF-I via reduc- 
tion of both liver IGF-I mRNA and IGFBP-3 availability. We attempted to discover: $(a)$ if loss of GHBP explains the reported reductions in circulating GH levels during food restriction (12, $23,29) ;(b)$ the threshold and time at which limited calories or protein, without micronutrient, protein (low calorie diets) and fat undernutrition, reduce total serum IGF-I; $(c)$ whether the mechanism for this IGF-I response involves reductions in IGFBPs, IGFBP-3-specific protease activity, the $150-\mathrm{kD}$ complex, or liver IGF-I mRNA.

\section{Methods}

\section{Design}

Pilot study. A pilot study was performed to establish the level of caloric restriction needed to reduce serum IGF-I levels in young adult rats. Male Sprague-Dawley (Harlan Sprague-Dawley, Indianapolis, IN) rats were housed individually in hanging wire-mesh cages. Rats were fed isocaloric, defined diets (3.90 calories/g) for $21 \mathrm{~d}$ as follows: ad lib. control (AIN-76A; control; $n=6$ ), or restricted to $75 \%(n=7)$ and $60 \%(n=6)$ the calories consumed by control. The results of this study led to the $60 \%$ and $40 \%$ calorie diets in the study reported below.

Animals and groups. 8-wk-old male Sprague-Dawley rats were housed individually in hanging wire-mesh cages in a temperature $\left(22^{\circ} \mathrm{C} \pm 2\right)$ and light $(12: 12 \mathrm{~h}$ light-dark cycle; light off at 9:00 a.m.) controlled room. After adaptation to conditions, handling, and a defined $\operatorname{diet}$ (AIN-76A; Dyets, Inc.; Bethlehem, PA), rats were randomly placed into one of six weight-matched groups ( $282 \mathrm{~g} \pm 2$; mean $\pm \mathrm{SE}$ ). Rats were fed isocaloric, defined diets ( 3.90 calories $/ g$ ) for $30 \mathrm{~d}$ as follows: ad lib. control (AIN-76A; control; $n=7$ ), ad lib. 4\% casein (low protein diet [LoPro]; $n=8)$, or restricted to $60 \%(n=7)$ and $40 \%$ $(n=8)$ the calories consumed by control. The $60 \%$ and $40 \%$ diets were formulated such that protein, fat, vitamin, and mineral consumption (grams) was equivalent to control intake to avoid protein and micronutrient undernutrition. Body weights and 24-h food intakes, corrected for spillage, were measured daily between 8:00 and 9:00 a.m. The amount of food fed to the $60 \%$ and $40 \%$ groups was calculated as that percentage of the control group's previous day food intake (grams). All food cups were returned to the cages immediately before lights off. On days 0,7 , and $21,0.3 \mathrm{ml}$ of blood was collected from the tail vein of nonfasted rats and serum was frozen at $-70^{\circ} \mathrm{C}$. On day 30 , rats were killed by $\mathrm{CO}_{2}$ and cardiac puncture. Serum samples were collected and frozen at $-70^{\circ} \mathrm{C}$ until assayed for IGF-I, IGFBPs, IGFBP-3 protease, and GH. The pulsatile pattern of GH secretion can also be measured to assess GH pulse height or frequency. However, the necessary cannulation of the malnourished animals and intense serial blood sampling would have added significant surgical and handling stress. Accordingly, as GH status was not the most important variable and given the added stress, we chose to measure serum GH concentrations from samples taken at a single time-point.

Liver samples were frozen at $-70^{\circ} \mathrm{C}$ or fixed in $10 \%$ neutral buffered formalin. As an indicator of carcass adiposity (30), retroperitoneal fat pad was weighed. Thymus, gastrocnemius, and adrenals were weighed and expressed as the fraction of body weight. This protocol was approved by the Protocol Review Committee and Institutional Animal Care and Use Committee of our AAALAC-approved vivarium.

\section{Analytical Procedures}

Hematology, blood chemistry, and liver histology. Hematology (hemoglobin, hematocrit) was performed on a Serono Baker 9000 unit (Serono Baker Diagnostics, Inc., Allentown, PA) with veterinary discriminator settings. 20 serum chemistry parameters were measured on a Hitachi analyzer (Tokyo, Japan). Sections of liver were harvested from each animal, fixed in $10 \%$ neutral buffered formalin, processed routinely to paraffin blocks, sectioned at $4 \mu \mathrm{m}$, and stained with hematoxylin and eosin by standard procedures.

Serum $G H$. Serum $\mathrm{GH}$ concentrations $(\mathrm{ng} / \mathrm{ml})$ were measured utiliz- ing a double antibody ELISA assay. Briefly, ELISA plates were coated with a goat anti-rat GH antibody. After incubation and washing, National Institutes of Health standard rat GH-RP-2 or $100 \mu \mathrm{l}$ of serum (1:50 dilution) was applied to wells and incubated at room temperature with gentle agitation for $2 \mathrm{~h}$. Sheep anti-rat GH antibody was then applied and plates were incubated at room temperature for $2 \mathrm{~h}$. After washing, Kirkegaard and Perry 2-component tetramethyl benzidine substrate solution was applied. The reaction was stopped with $\mathrm{H}_{3} \mathrm{PO}_{4}$ and the optical density read at $450 \mathrm{~nm}$.

Serum GHBP. Rat GHBP was assayed using an RIA method (31) and values are expressed as nanograms rhGHBP per milliliter serum.

Serum IGF-I concentrations. Before measurement of serum total IGF-I, high molecular weight IGFBP's were precipitated by incubating in acid-ethanol $(12.5 \% 2 \mathrm{~N} \mathrm{HCl}, 87.5 \% \mathrm{EtOH})$ at $4^{\circ} \mathrm{C}$ for $30 \mathrm{~min}$ (32). There was incomplete recovery of IGF-I if lesser ratios than 1:15 serum to acid-ethanol were used. Samples were then centrifuged for 5 $\min$ at $10,000 \mathrm{~g}$. Supernate was neutralized with $1 \mathrm{M}$ Tris base, and diluted in PBS pH 7.4 with $0.1 \%$ gelatin, $0.05 \%$ Tween 20 and $0.01 \%$ thimerosal. Serum IGF-I concentrations were determined that same day by radioimmunoassay (33). The percentage recovery of recombinant human IGF-I (Genentech, Inc.) added to samples extracted as above was $91.1 \pm 9.9 \%$ (mean $\pm \mathrm{SE} ; n=4)$.

SDS-PAGE and Western ligand blotting. Serum IGFBP profiles were measured on 7-, 21-, and 30-d samples. Serum $(2.5 \mu \mathrm{l})$ was diluted with nonreducing SDS sample buffer ( $0.5 \mathrm{M}$ Tris, $\mathrm{pH} 6.8 ; 69 \%$ glycerol; $4 \%$ SDS), applied to a $4 \%$ stacking gel and electrophoresed through $11 \%$ polyacrylamide gel. Size-fractionated proteins were then transferred to nitrocellulose according to Towbin, et al. (34). Western ligand blotting was performed following the method of Hossenlopp, et al. (35) as previously described (25), using $\sim 1 \times 10^{6} \mathrm{cpm}{ }^{125} \mathrm{I}$-IGF-I and ${ }^{125} \mathrm{I}-$ IGF-II. Densitometry was performed using the BAS2000 phosphorimager (Fuji, Inc., Tokyo, Japan). Relative quantities of IGFBP-3 were determined after scanning the bands corresponding to $40-45 \mathrm{kD}$. At least three separate control sera were run on each gel and IGFBP-3 values are reported as percentage of control \pm SE.

IGFBP-3 molecular distribution. It is possible that nutritional state will change the $150-\mathrm{kD}$ trimer complex that carries the majority of IGFI in the circulation. For example, more dimer or free IGF-I could result in faster clearance of IGF-I and thereby be a mechanism to lower total serum IGF-I levels. To determine the molecular weight distribution of endogenous IGFBP-3, pooled serum samples $(200 \mu \mathrm{l})$ were size fractionated at neutral $\mathrm{pH}$ on a Super-Dex 200 column (Pharmacia LKB Biotechnology; Uppsala, Sweden) at a flow rate of $0.5 \mathrm{ml} / \mathrm{min}$ and 0.5-ml fractions were collected. Fractions 7-20 ( 300-20 kD) were analyzed by Western ligand blotting as described above.

Serum IGFBP-3-specific protease activity. Recombinant ${ }^{125} \mathrm{I}-$ IGFBP-3 $\left(30,000 \mathrm{cpm}\right.$ in $5 \mu 120 \mathrm{mM}$ Hepes $+1 \mathrm{mM} \mathrm{CaCl}_{2}, \mathrm{pH} 7.2$; Diagnostic Systems Laboratory, Inc., Webster, TX) was incubated for $5 \mathrm{~h}$ at $37^{\circ} \mathrm{C}$ with $20 \mu \mathrm{l}$ diluted test serum (1:10 vol/vol serum: $20 \mathrm{mM}$ Hepes $+1 \mathrm{mM} \mathrm{Ca} \mathrm{Cl}, \mathrm{pH} \mathrm{7.2)}$. The reaction was terminated by the addition of nonreducing SDS sample buffer, the radiolabeled fragments separated by SDS-PAGE on a $15-\mathrm{cm}$ gel under nonreducing conditions and the bands visualized via autoradiography. To control for spontaneous degradation of ${ }^{125} \mathrm{I}$-IGFBP-3 during the incubation period, a sample containing 30,000 cpm ${ }^{125}$ I-IGFBP-3 in buffer alone was included.

Liver IGF-I mRNA isolation. Liver total RNA was isolated from $200 \mathrm{mg}$ of frozen liver homogenized in $1 \mathrm{ml}$ of $5 \mathrm{M}$ guanidium thiocyanoate buffer containing $1 \%$ beta-mercaptoethanol. Samples were phenol-chloroform (1:1) extracted and centrifuged at 14,000 $g$ for 10 $\min$. The aqueous phase was removed and precipitated with $8 \mathrm{M} \mathrm{LiCl}$ overnight at $-20^{\circ} \mathrm{C}$. Samples were centrifuged at $14,000 \mathrm{~g}$ for $25 \mathrm{~min}$ at $4^{\circ} \mathrm{C}$. The supernate was removed and the pellet was resuspended in $3 \mathrm{M} \mathrm{LiCl}$, centrifuged at $14,000 \mathrm{~g}$ for $10 \mathrm{~min}$ at $4^{\circ} \mathrm{C}$. The supernate was removed and the pellet resuspended in $1 \times$ SET ( $1 \%$ sodium dodecyl sulfate, $10 \mathrm{mM}$ Tris, ph 8.0, and $5 \mathrm{mM}$ EDTA, ph 8.0), treated with $200 \mu \mathrm{g} / \mathrm{ml}$ proteinase-K (Boehringer Mannheim Biochemicals, Indianapolis, IN) for $1 \mathrm{~h}$ at $45^{\circ} \mathrm{C}$, phenol-chloroform (1:1) extracted 
Table I. Serum GH and GHBP concentrations

\begin{tabular}{|c|c|c|c|c|}
\hline & Control & $60 \%$ & $40 \%$ & LoPro \\
\hline \multicolumn{5}{|c|}{ GHBP (ng/ml) } \\
\hline Day 30 & $21.0 \pm 0.7^{* \neq}$ & $18.3 \pm 1.1^{\ddagger}$ & $12.2 \pm 1.1^{8}$ & $22.2 \pm 0.8^{*}$ \\
\hline \multicolumn{5}{|c|}{$\mathrm{GH}(\mathrm{ng} / \mathrm{ml})$} \\
\hline Day 0 & $97.4 \pm 65$ & $63.1 \pm 29.3$ & $33.6 \pm 14.1$ & $102 \pm 52$ \\
\hline Day 7 & $54.3 \pm 11.2^{*}$ & $25.3 \pm 10.7^{\ddagger}$ & $29.5 \pm 8.9^{* \neq}$ & $12.2 \pm 4.7^{*}$ \\
\hline Day 21 & $66.3 \pm 35.2$ & $31.7 \pm 9.4$ & $5.5 \pm 2.3$ & $12.2 \pm 8.3$ \\
\hline Day 30 & $67.8 \pm 31.9 *$ & $3.5 \pm 1.7^{\ddagger}$ & $4.8 \pm 2.1^{\ddagger}$ & $32.6 \pm 15.2^{* *}$ \\
\hline
\end{tabular}

The mean $\pm \operatorname{SEM}(n=7-8)$ is represented for serum collected on given days. Superscripts denote significant differences between treatment groups; means not sharing the same superscripts are different at $P$ $<0.05$; means without superscripts are not different.

and precipitated with 1 vol isopropanol and $1 / 10$ vol $3 \mathrm{M} \mathrm{NaOAc}$ at $-20^{\circ} \mathrm{C}$ until assayed.

Liver IGF-I and cyclophilin mRNA, solution hybridization protection assay. Liver IGF-I and cyclophilin mRNA were quantified following procedures described previously (36). A 209-bp segment of the rat IGF-I gene, containing 41 bases of exon 3 and all of exon 4 was subcloned into the phagemid pBluescriptIISK(+). A 110-bp segment of the rat cyclophilin gene was subcloned into the phagemid pBluescriptKS (+) (Stratagene, La Jolla, CA). Sense RNA standards and antisense RNA probes (labeled to $10^{9} \mathrm{cpm} / \mu \mathrm{g}$ with [ ${ }^{32} \mathrm{P}$ ] UTP) were generated using commercially available transcription reagents and protocols (Stratagene). Samples were reconstituted in $1 \times \mathrm{TE}(10 \mathrm{mM}$ Tris, pH 8.0 and $1 \mathrm{mM}$ EDTA, pH 8.0). The concentrations of RNA in each sample was determined from a measurement of the absorbance of $\mathrm{OD}_{260 \mathrm{~nm}} .10 \mu \mathrm{g}$ of each RNA sample (in $5 \mu \mathrm{l} 1 \times \mathrm{TE}$ ) was assayed. The sense RNA standard was quantified by absorbance at $\mathrm{OD}_{260 \mathrm{~nm}}$ and diluted in $1 \times \mathrm{TE}$ for addition into the assay in $5 \mu \mathrm{l} 1 \times \mathrm{TE}$; standards were run in the range from 0.5 to $600 \mathrm{pg} /$ tube. $25 \mu \mathrm{l}$ of hybridization buffer (36) containing $1 \mathrm{ng}$ of each antisense RNA probe (quantitated by incorporation of ${ }^{32} \mathrm{P}$ and resuspended in hybridization buffer) were added and the reactions were heated to $85^{\circ} \mathrm{C}$ for $5 \mathrm{~min}$, then incubated overnight at $45^{\circ} \mathrm{C}$.

Hybridizations were digested with $0.2 \mathrm{ml}$ RNAse digestion mix (36) for $1 \mathrm{~h}$ at $30^{\circ} \mathrm{C}$, followed by treatment with sodium dodecyl sulfate and proteinase- $\mathrm{K}$ for $15 \mathrm{~min}$ at $37^{\circ} \mathrm{C}(36)$. The protected RNA:RNA hybrids were phenol-chloroform extracted, precipitated with $100 \%$ ethanol, and electrophoresed through nondenaturing polyacrylamide gels. The gels were dried and exposed to $x$-ray film, and the bands formed by the protected RNA:RNA hybrids were visualized on a BAS2000 phosphorimager for quantitation. The concentration of RNA was computed by comparing the density of the samples to a standard curve generated by the linear regression of density vs picogram of sense standard (36).

Statistical analyses. Results are given as means \pm SE. Data were analyzed by one-way ANOVA and subsequent post-hoc tests were performed using Fisher's PLSD test. For all analyses, a $P$ value of $<0.05$ was considered significant.

\section{Results}

Pilot study. Compared to the circulating IGF-I measured in ad lib. fed controls $(365 \pm 18 \mathrm{ng} / \mathrm{ml})$, restriction to $60 \%$ of normal intake for $21 \mathrm{~d}$ insignificantly decreased serum IGF-I (316 21 $\mathrm{ng} / \mathrm{ml}$ ) and diet restriction to $75 \%$ had no effect $(408 \pm 32 \mathrm{ng} /$ $\mathrm{ml}$ ). Given this surprising result, the final experiment imposed a more severe and prolonged calorie restriction on these young adult animals.

General health, food consumption, and body weight. No
Table II. Total Serum IGF-I Concentrations (ng/ml)

\begin{tabular}{lllll}
\hline Day & Control & \multicolumn{1}{c}{$60 \%$} & $40 \%$ & \multicolumn{1}{c}{ LoPro } \\
\hline 0 & $593 \pm 36$ & $610 \pm 20$ & $590 \pm 14$ & $576 \pm 19$ \\
7 & $575 \pm 23^{*}$ & $512 \pm 24^{\ddagger}$ & $443 \pm 15^{\S}$ & $362 \pm 15^{\| \prime}$ \\
21 & $554 \pm 22^{*}$ & $502 \pm 14^{*}$ & $396 \pm 31^{\ddagger}$ & $396 \pm 23^{\ddagger}$ \\
30 & $582 \pm 34^{*}$ & $513 \pm 19^{\ddagger}$ & $339 \pm 13^{\S}$ & $391 \pm 15^{\text {॥ }}$
\end{tabular}

The mean $\pm \operatorname{SEM}(n=7-8)$ is represented for serum collected on given days. Superscripts denote significant differences between treatment groups; means not sharing the same superscripts are different at $P$ $<0.05$; means without superscripts are not different.

animals died or were judged clinically sick during the course of this protocol. Cumulative food intake in grams was as follows: control, $590 \pm 12$; LoPro, $561 \pm 18 ; 60 \%$, 357 $\pm 1 ; 40 \%, 241 \pm 0.3$. Control rats consistently gained weight from day $0(281 \mathrm{~g} \pm 6)$ to day 30 (391 \pm 7$)$. Reduction to $60 \%$ of control intake yielded a modest weight gain from day $0(281 \pm 4)$ to day $30(306 \pm 4)$. In contrast, a reduction to $40 \%$ of control intake resulted in steady body weight loss from day $0(281 \pm 4)$ until $\sim$ day 20 , followed by maintenance of body weight to day $30(238 \pm 2)$. The rats fed the LoPro diet (day 0: 282 44) initially lost weight and then tracked with the $60 \%$ group to day 30 (304 \pm 4$)$. In summary, by day 30 the controls had gained $39 \%$ body weight, while $60 \%, 40 \%$, and LoPro body weights were $+9,-15$ and, $+8 \%$ of day 0 , respectively.

Serum GH, GHBP, and IGF-I concentrations. The serum GH concentrations were markedly reduced in the $40 \%$ and $60 \%$ groups, whereas the serum GH concentrations of LoPro group was halved but not significantly different from controls at day 30 (Table I). Serum GHBP concentrations of the $40 \%$ group were lower, while those of the $60 \%$ and LoPro groups were similar to controls (Table I). Table II lists the changes in serum IGF-I concentrations over the 30-d period. These were similar among the groups on day 0 , but by day 7 , IGF-I declined in the restricted groups, particularly in the LoPro rats. On day 21 , IGF-I levels were similarly low in the $40 \%$ and LoPro rats. On day 30 , serum IGF-I levels were slightly lower in the $60 \%$, and further reduced in the $40 \%$ and LoPro rats compared to controls.

Serum IGF binding proteins. Serum IGFBP-3 levels of the $60 \%$ rats were unchanged through the month while $40 \%$ and LoPro rats had a $20-30 \%$ reduction in IGFBP-3 (Fig. 1).

Serum IGFBP-3 molecular distribution. While it was evident that there was decreased total IGFBP-3 in the $40 \%$ and LoPro groups, energy and protein deprivation had no effect on the overall molecular distribution of IGFBP-3 in serum (Fig. 2 ). The concept was that a change in this distribution pattern would suggest another mechanism for lowering total IGF-I via an alteration in either the binding affinities and/or availability of IGFBP-3 and/or the acid-labile subunit. Regardless of diet, the majority of IGFBP-3 was bound to the acid-labile subunit and IGF-I in the $150-\mathrm{kD}$ trimer, while a smaller proportion of serum IGFBP-3 was found in the 55-kD complex.

Serum IGFBP-3 protease activity. All rats had measurable IGFBP-3 protease activity, as illustrated in Fig. 3. When compared to the amount of IGFBP-3 protease activity present in pregnant rat serum, none of the diet treatments had increased IGFBP-3 protease activity as witnessed by little change in the amounts of low molecular weight IGFBP-3 fragments. 

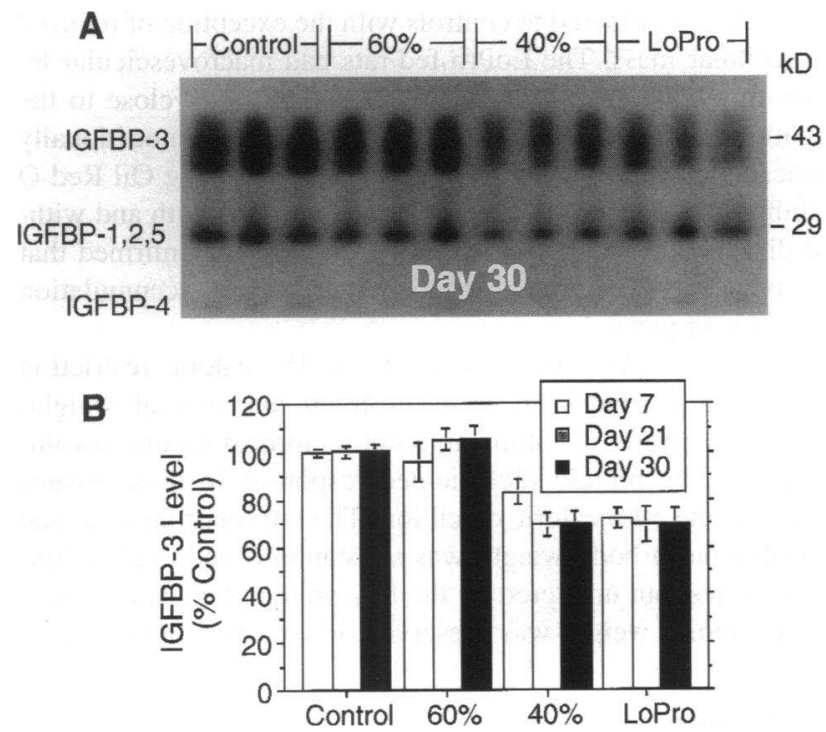

Figure 1. (A) Autoradiograph of Western ligand blot of serum IGFBPs. Rats were fed control diet ad lib., a low protein diet ad lib. (LoPro), or restricted to 60 and $40 \%$ the calories consumed by controls for 30 d. (B) Time course of the nutritionally induced alterations in serum IGFBP-3 concentrations is shown in the graph. All IGFBP-3 concentrations are expressed as a percent of control values. Data are presented as means $\pm \operatorname{SE}(n=6-8)$.

Liver IGF-I mRNA. Liver IGF-I mRNA expressed as picogram/microgram total RNA was decreased by 25 and $33 \%$ in the $40 \%$ and LoPro groups, respectively, (control, $5.8 \pm 0.5$; $60 \%, 5.2 \pm 0.7 ; 40 \%, 4.3 \pm 0.2 *$; LoPro, $3.9 \pm 0.1 * ; * P=0.024$ ). Liver cyclophilin mRNA was used to normalize the IGF-I measurement, as cyclophilin was considered a constitutive cell component. We found that liver cyclophlin mRNA content was similar between control, $60 \%$, and $40 \%$ groups, but was increased in the LoPro rats (pg cyclophilin/ $\mu$ g total RNA: control,

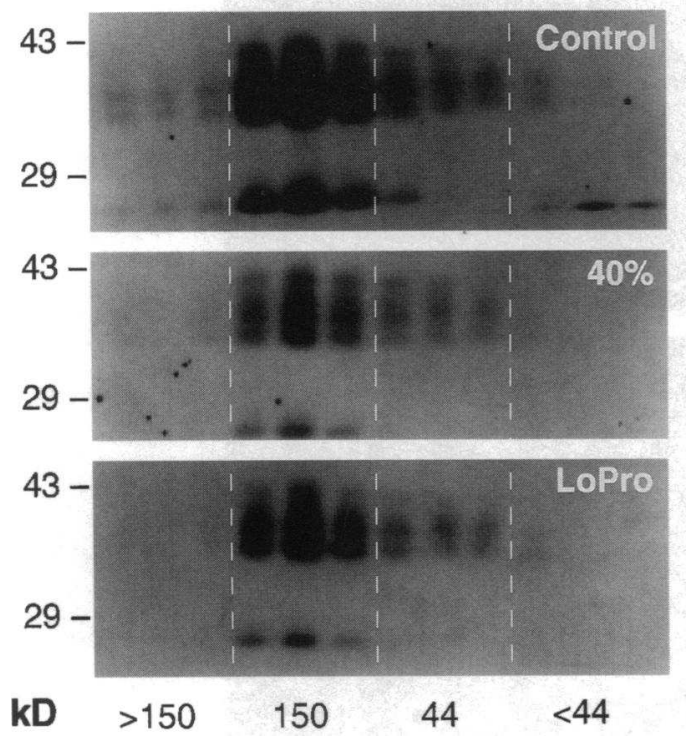

Figure 2. Autoradiograph of IGFBP-3 molecular distribution. Rats were fed control diet ad lib., a low protein diet ad lib. (LoPro), or restricted to $40 \%$ the calories consumed by controls for $30 \mathrm{~d}$.

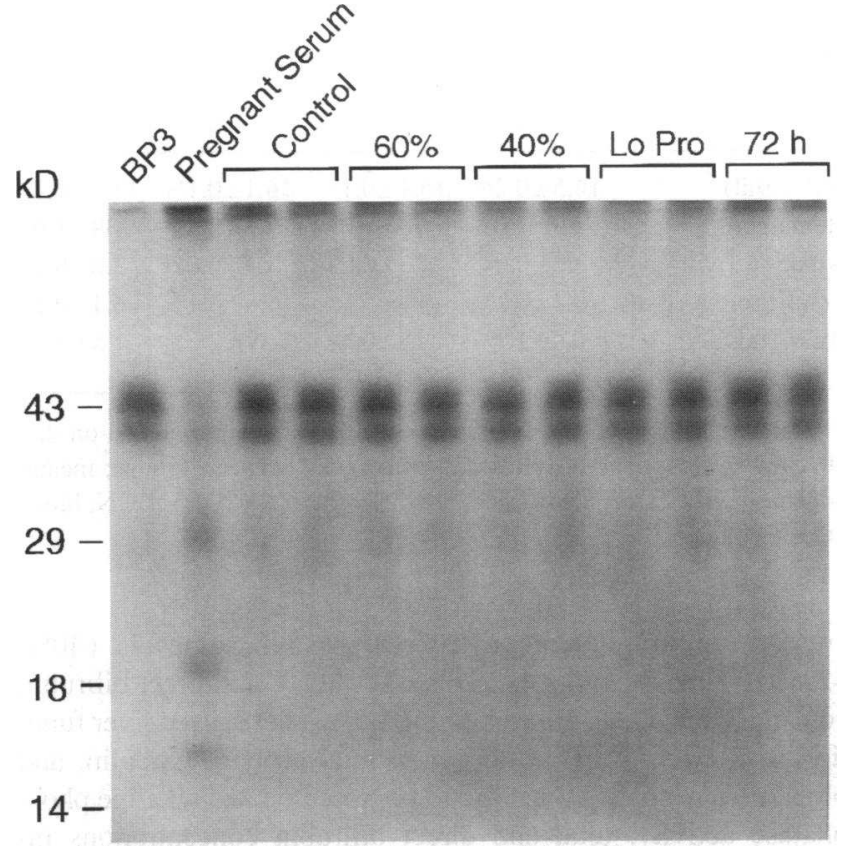

Figure 3. Autoradiograph of IGFBP-3 protease activity in rats fed control diet ad lib., a low protein ad lib. (LoPro), or restricted to 60 and 40\% control calories for $30 \mathrm{~d}$. (Pregnant rat serum) Serum from pregnant female Sprague-Dawley rat. Each lane represents a different animal.

$2.8 \pm 0.1 ; 60 \%, 2.5 \pm 0.2 ; 40 \%, 2.8 \pm 0.1 ;$ LoPro, $3.7 \pm 0.3 * ; * P$ $<0.001$ ). The ratio of liver IGF-I mRNA to cyclophilin mRNA was decreased to a greater extent in the LoPro than in the $40 \%$ group (Fig. 4).

Serology. Hemoglobin, hematocrit, blood urea nitrogen and serum albumin, and total protein values are listed in Table III. Although there were statistical differences in hemoglobin concentrations and hematocrits, these group means are within nor$\mathrm{mal}$ ranges. The similar albumin and total protein concentrations of the energy deprived groups (60\% and $40 \%$ ) compared to controls, demonstrate that these malnourished groups were adequately protein nourished. Caloric restriction to $40 \%$ of normal caused some impairment of liver function as measured by in-

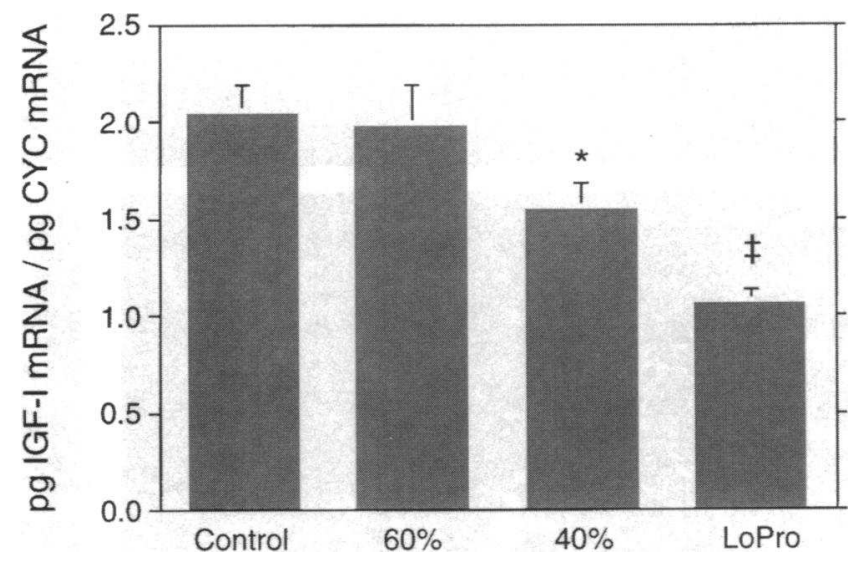

Figure 4. Quantitation of liver IGF-I mRNA expressed as picogram/ picogram cyclophilin (CYC) mRNA is shown for rats fed control diet ad lib., a low protein diet ad lib. (LoPro), or restricted to 60 and $40 \%$ control calories. Means \pm SE. ${ }^{*},{ }^{\ddagger}, P<0.05$ vs other groups. 
Table III. Selected Serum Chemistry and Hematology Values on Day 30

\begin{tabular}{lcccr}
\hline & Control & $60 \%$ & $40 \%$ & LoPro \\
\hline Hgb (g/dl) & $14.5 \pm 0.2^{*}$ & $15.1 \pm 0.1^{\ddagger}$ & $16.1 \pm 0.1^{8}$ & $13.9 \pm 0.2^{11}$ \\
Hematocrit (\%) & $39 \pm 1.0^{*}$ & $40 \pm 1.0^{*}$ & $43 \pm 0.4^{\ddagger}$ & $39 \pm 1.0^{*}$ \\
Albumin (g/dl) & $3.2 \pm 0.04^{*}$ & $3.3 \pm 0.04^{*}$ & $3.3 \pm 0.02^{*}$ & $3.0 \pm 0.1^{\ddagger}$ \\
Total Protein (g/dl) & $6.8 \pm 0.1^{*}$ & $6.7 \pm 0.1^{*}$ & $6.8 \pm 0.1^{*}$ & $6.1 \pm 0.2^{\ddagger}$ \\
BUN (mg/dl) & $14 \pm 1^{*}$ & $15 \pm 0.4^{*}$ & $19 \pm 2^{\ddagger}$ & $5 \pm 1^{8}$ \\
\hline
\end{tabular}

The mean \pm SEM $(n=7-8)$ is represented for serum collected on day 30. Superscripts denote significant differences between groups; means not sharing the same superscripts are different at $P<0.05$. BUN, blood urea nitrogen.

creased serum glutamic pyruvic transaminase levels $(40 \%$, $42 \pm 2 \mathrm{IU} /$ liter vs control, $28.6 \pm 2 \mathrm{IU} /$ liter) and direct bilirubin concentration. Consumption of the LoPro diet caused liver function to decline as serum albumin, total protein, globulin, and blood urea nitrogen concentrations decreased and alkaline phosphatase activity, total and direct bilirubin concentrations increased. All animals were euglycemic at time of death. The following serum chemistries were similar across all groups: serum glutamic oxaloacetic transaminase, creatine phosphokinase, creatinine, bicarbonate, calcium, sodium, chloride, potassium, and indirect bilirubin. Phosphorus concentrations were low in all diet treatment groups compared to controls.

Liver histology. To describe the effects of energy and protein deficiency on the liver, histology sections were evaluated (Fig. 5). In the $40 \%$ group, there was no marked difference in morphology compared to controls with the exception of reduced intracellular mass. The LoPro-fed rats had macrovescicular lesions throughout the liver with a greater severity close to the hepatic triad, consistent with the development of a nutritionally induced steatotic liver. In a subsequent study, using Oil Red O staining for fat and Periodic acid Schiff reaction with and without diastase digestion for glycogen content, we confirmed that this pathology was associated with triglyceride accumulation (data not shown).

Organ weights. As listed in Table IV, calorie restriction resulted in a graded increase in fractional adrenal weight, whereas there was a comparable but reciprocal thymic involution. The low protein diet yielded responses in these tissues similar to the $60 \%$ calorie condition. The retroperitoneal fat pad contribution to body weight was substantially reduced by limited calories, but unaltered by the low protein diet. The relative gastrocnemius weight was preserved, irrespective of treatment.

\section{Discussion}

While a broad spectrum of macro- and micronutrient deficiencies are capable of suppressing serum IGF-I concentrations, the IGF-I response may vary with age, type or degree of inadequacy, and length of malnutrition. Although serum IGF-I levels were low in protein energy-malnourished children and adults $(5,6,7,37)$, there appeared to be a critical threshold before IGF-I concentrations declined (3). The level of energy intake which supports normal circulating IGF-I was indicated in a study by Kupfer, et al. (38). Humans $22-47$ yr of age were restricted to $\sim 2 / 3$ ad lib. intake (i.e., 20 calories per kilogram ideal body weight with $1 \mathrm{~g}$ protein per kilogram). Subjects lost
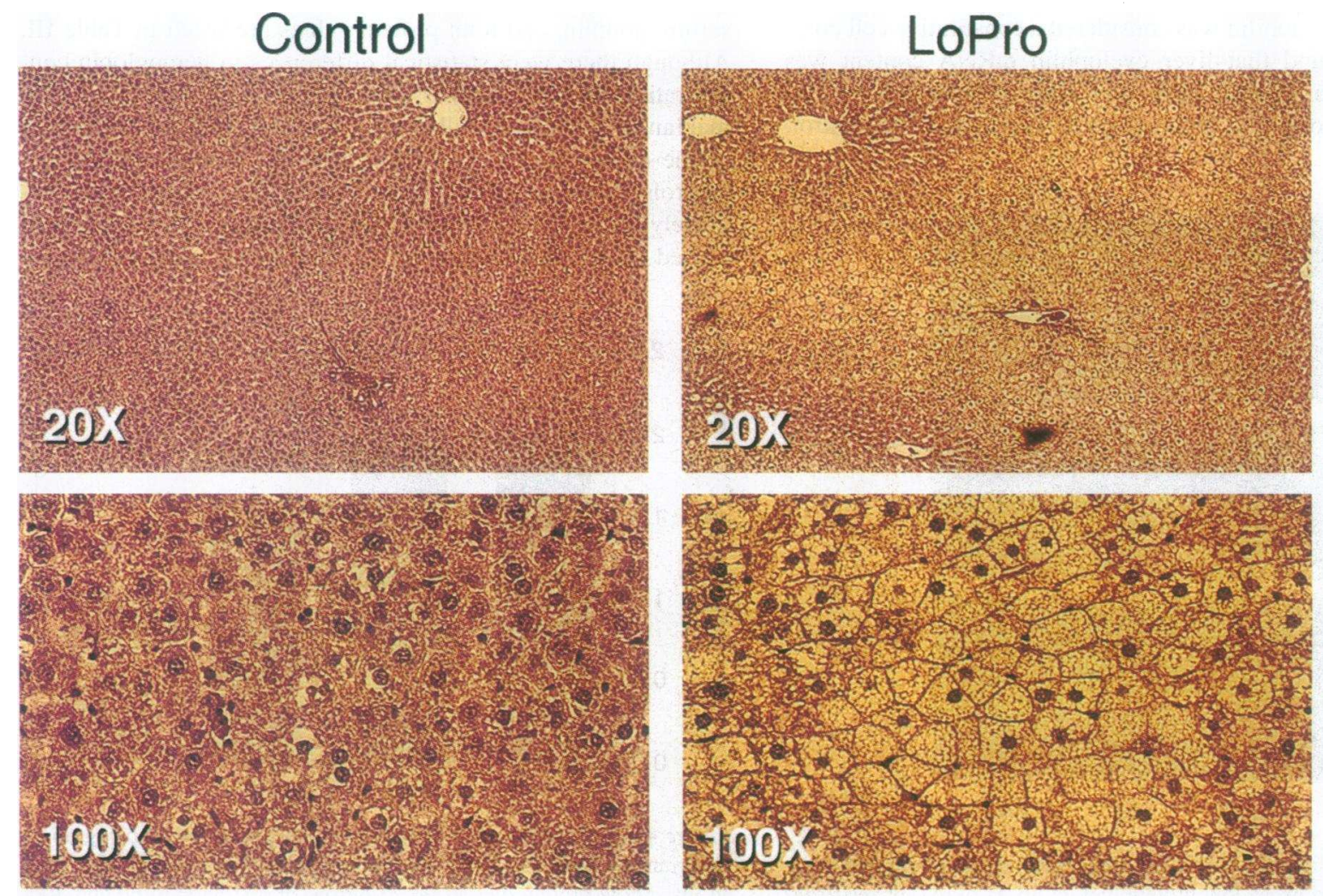

Figure 5. Comparison of liver sections of rats fed control diet ad lib. or a low protein diet ad lib. (LoPro). (Top) $\times 20 ;($ Bottom $) \times 100$. 
Table IV. Retroperitoneal Fat, Gastrocnemius Muscle, Adrenal, and Thymic Wet Weight Fraction on Day 30

\begin{tabular}{lcccc}
\hline & \multicolumn{4}{c}{ Tissue Weight/Body Weight $\times 10^{-3} \mathrm{~g}$} \\
\cline { 2 - 5 } & Control & $60 \%$ & $40 \%$ & LoPro \\
\hline RP fat & $517 \pm 46^{*}$ & $199 \pm 31^{\ddagger}$ & $75 \pm 20^{\S}$ & $634 \pm 46^{\|}$ \\
Muscle & $428 \pm 34^{*}$ & $535 \pm 25^{\ddagger \S}$ & $586 \pm 22^{\ddagger}$ & $517 \pm 13^{\S}$ \\
Adrenal & $7.9 \pm 0.4^{*}$ & $8.3 \pm 0.4^{*}$ & $11 \pm 0.6^{\ddagger}$ & $8.3 \pm 0.3^{*}$ \\
Thymus & $135 \pm 10^{*}$ & $117 \pm 7^{*}$ & $84 \pm 5^{\ddagger}$ & $119 \pm 7^{*}$ \\
& & & & \\
\hline
\end{tabular}

The mean $\pm \operatorname{SEM}(n=7-8)$ is represented. Superscripts denote significant differences between groups; means not sharing the same superscripts are different at $P<0.05$. RP, retroperitoneal.

an average of $3 \mathrm{~kg}$ during $1 \mathrm{wk}$ of restriction with no change in serum IGF-I levels. The results of these human studies appear similar to the minimal IGF-I decline $(12 \%)$ observed in rats restricted to $60 \%$ calories, with greater decreases associated with the more severe diets (Table II).

We controlled multiple nutritional variables so that the effects of energy and protein deficiency per se on circulating $\mathrm{GH}$ and IGF-I levels could be directly compared, without micronutrient or fat undernutrition. This is the first report of protein and carbohydrate restriction impact on molecular distribution of IGFBP-3, IGFBP-3-specific protease activity, and GHBP levels. In the rodent, GHBP is derived by alternative splicing during the processing of the full-length GH receptor pre-mRNA, and GHBP levels can be correlated with hepatic GH receptor binding in adult animals $(39,40)$. Although the primary source of GHBP is thought to be the liver, the broad tissue distribution of GHBP mRNA expression suggests that GHBP may have autocrine/paracrine roles in modulating $\mathrm{GH}$ action or in regulating GH presentation to or removal from target tissues (40).

While there are no adult animal studies that specifically limit dietary carbohydrate calories, $65 \%$ restriction of overall food and micronutrient intake suppressed pulsatile GH release and $\mathrm{GH}$ levels in adult rats (29). In the current study, the groups limited to $60 \%$ and $40 \%$ of ad lib. calorie intake had markedly reduced serum GH by day 30 . This suggests that GH status is ultimately sensitive to carbohydrate calories independent of protein, fat, and micronutrient availability. Though pulsatile $\mathrm{GH}$ was not measured with intense blood sampling, there is a strong and significant trend suggested from the single samples. The $40 \%$ diet induced an order of magnitude inhibition of GH by day 21 , while the $60 \%$ diet preserved higher ambient GH levels through at least $3 \mathrm{wk}$. This observation in $40 \%$ vs $60 \%$ groups was independently confirmed in a recent 21 day study (data not shown). The $40 \%$ calorie group was also the only set of rats that had reduced GHBP and lost body weight throughout the month.

In a previous study, 1-mo-old male Sprague-Dawley rats fed 70,60 , or $50 \%$ of ad lib. intake for $10 \mathrm{~d}$ had 39,58 , and $80 \%$ reductions in liver IGF-I mRNA, respectively (11). In that report, liver IGF-I mRNA levels were determined by Northern blot analysis using a cDNA probe which included the entire region protected by our exon 3 and 4 riboprobe. In contrast, we found that a reduction of energy intake to $60 \%$ did not significantly decrease liver IGF-I mRNA, either when expressed per microgram RNA or per picogram cyclophilin mRNA. In these 3 -mo-old rats, a severe energy restriction to $40 \%$ significantly reduced liver IGF-I mRNA. The dissimilarity between our findings and those of Straus and Takemoto (11) may reflect a differential sensitivity of liver IGF-I gene expression to dietary restriction as a function of age. Such a finding has already been described for protein malnourished rats (24).

Inhibition of GH may be necessary but is not sufficient to trigger the alteration in IGF-I and IGFBP-3 with severe energy restriction. Both of these proteins continued to fall after the first week, and then stabilized over the latter part of the month, indicating the value of longer protocols to understand the timing and degree of hormonal adaptation to calorie undernutrition. We conclude that there is a clear threshold of carbohydrate availability, between $\mathbf{4 0}$ and $60 \%$ of ad lib. calories, necessary to maintain body weight, serum GHBP, and IGF-I levels in adult rats.

In the protein-deficient state, decreased IGF-I production $(13,14,18)$ and increased IGF-I clearance (17) with normal GH $(14,19)$, reduced GH $(20,41)$ and normal GH binding $(14,18)$ have been described. For example, Lemozy et al. (22) recently found in pubertal female rats a $50 \%$ reduction of serum IGF-I after $8 \mathrm{~d}$ of a $5 \%$ (vs $15 \%$ control) protein diet. In our study, serum GHBP was surprisingly unchanged at day 30 in the low protein group (unlike severe calorie restriction) while serum GH only trended toward lower values. The IGF-I levels were down by a third at day 7 , and then maintained at this level, while hepatic IGF-I mRNA was significantly lowered with low protein availability, confirming shorter studies in younger animals $(19,23)$. Because liver is the major source of serum IGF-I and IGFBP-3, steatosis, a well-documented result of protein malnutrition $(42,43)$, may have hindered synthesis of IGF-I and IGFBP-3. Alternatively, limited essential amino acid availability from this diet could explain these responses, as suggested by diminished IGF-I gene transcription in cultured hepatocytes exposed to reduced low amino acids (44). However, normal GHBP levels at day 30 in the low protein group challenges this concept of a generalized hepatic dysfunction, as liver is thought to be the predominant source of circulating GHBP (40).

A role for IGFBP proteases has been postulated to contribute to the decline in IGFBP-3 (19). The hypothesis we tested for the first time was that these enzymes participate in the response to catabolic conditions, possibly promoting tissue availability or clearance of decomplexed IGF-I and/or IGFBP-3. Increased IGF-I clearance was noted in young protein-restricted rats (17), though the mechanism was not ascertained. Furthermore, proteolytic activity directed at IGFBPs was reported in pregnancy $(25,26)$, surgery $(28)$, and severe illness $(27)$. Given these published data, we predicted that an IGFBP-3 protease would be more active in severe protein and/or calorie malnutrition. It was also expected that there would be a conversion of the 150 $\mathrm{kD}$ complex containing IGF-I into a smaller form. Contrary to these speculations, at day 30 there was a change in neither IGFBP-3 protease nor the distribution of the $150-\mathrm{kD}$ complex. We conclude that IGFBP-3 proteolysis does not contribute to the decline of serum IGF-I or IGFBP-3 during marked protein or calorie deficiency in this model. We now postulate that the fall in serum IGFBP-3 is via a drop in its transcription or translation. This would be supported by the single data point indicating lower liver IGFBP-3 mRNA in rats suckled on dams fed at $50 \%$ of normal (45).

The greatly diminished adiposity of the caloric- vs proteinrestricted state (Table IV) confirms that the compensatory 
mechanisms reacting to each deficit are fundamentally different. In adult rats, protein deficiency results in trunkal proteolysis to supply amino acid substrates (46), without an overall decrease in percent body fat (47). In contrast, limited dietary calories elicits both lipolysis and conservation of protein nitrogen. The fact that fat stores were nearly depleted indicated that the animals were nearing or in an energy crisis after $30 \mathrm{~d}$; the adrenal data would support this interpretation. Regarding the thymus, we knew that IGF-I infusions into hypophysectomized (48) or old (49) rodents increased thymic weight as well as $T$ cell number and function (49). Accordingly, we predicted that severe undernutrition would reduce both IGF-I levels and thymic size. However, of the two groups with the lowest circulating IGF-I levels (40\% and LoPro), only the $40 \%$ group had depressed thymic weight. This was also the only group showing increased adrenal weight, a hallmark of sustained stress (50). Adrenal weight and elevated glucorticoid output is also correlated with a decrease in relative thymic weight (51), allowing the concept that adrenal hyperactivity was a likely cause of the smaller thymus in the $40 \%$ group.

In summary, the comparative adaptation of the somatotrophic hormones to chronic, substantial, and specific protein or calorie deficiency was evaluated. Over a 30-d study in adult rats, serum GH was markedly reduced in the $40 \%$ calorie group by day 21 , but was more modestly lowered in the $60 \%$ calorie and low protein animals. Interestingly, serum GHBP was significantly decreased by about half only in the $40 \%$ calorie group. More consistent across groups was the finding that restricted calories or protein depressed serum IGF-I levels on day 30 , in the following rank order: $60 \%(-12 \%)$, LoPro $(-33 \%), 40 \%$ $(-42 \%)$. Chronic, severe energy ( $40 \%$ calorie group only) and protein deficits were required to observe a reduction in serum IGFBP-3, liver IGF-I mRNA, serum total protein, albumin, and blood urea nitrogen. These dietary regimens had no measurable impact on the association of IGFBP-3 with the circulating 150$\mathrm{kD}$ complex, which includes IGF-I and the acid-labile subunit. Reduced IGFBP-3 concentrations were also not due to a substantial increase in IGFBP-3-specific protease activity, characteristic of other conditions of lowered IGF-I and IGFBP-3.

We conclude that severe calorie and protein restriction of young adult rats produces only a modest fall in circulating IGFI ( $32-43 \%$ at day 30$)$, which is likely mediated by reductions in both liver IGF-I mRNA and serum IGFBP-3. These and other data indicate that there are broad ranges of nutrient intake and dietary composition which support normal circulating IGF-I and IGFBP-3 in young adult rodents and humans.

\section{Acknowledgments}

We thank Iain Robinson, Danielle Carmignac, Noel Dybdal, Wesley Won, Sammy Hernandez, Denise Harrison, Peter Bang, Ross Clark, Irene Figari, and the staff of the vivarium and histopathology facilities at Genentech, Inc.

\section{References}

1. Kotler D. P., A. R. Tierney, J. Wang, and R. N. Pierson. 1989. Magnitude of body-cell-mass depletion and the timing of death from wasting in AIDS. Am. J. Clin. Nutr. 50:444-447.

2. Kotler, D. P., J. Wang, and R. N. Pierson. 1985. Body composition studies in patients with the acquired immunodeficiency syndrome. Am. J. Clin. Nutr. 42:1255-1265

3. Thissen, J. P., J. M. Ketelslegers, and L. E. Underwood. 1994. Nutritional regulation of the insulin-like growth factors. Endocr. Rev. 15:80-101.
4. Sara, V. R., and K. Hall. 1990. Insulin-like growth factors and their binding proteins. Physiol. Rev. 70:591-614.

5. Grant, D. B., J. Hambley, D. Becker, and B. L. Pimstone. 1973. Reduced sulphation factor in undernourished children. Arch. Dis. Child. 48:596-600.

6. Hintz, R. L., R. Suskind, K. Amatayakul, O. Thanangkul, and R. Olson. 1978. Plasma somatomedin and growth hormone values in children with proteincalorie malnutrition. J. Pediatr. 92:153-156.

7. Soliman, A. R., A. E. H. I. Hassan, M. K. Aref, R. L. Hintz, R. G. Rosenfeld, and A. D. Rogol. 1986. Serum insulin like growth factors I and II concentrations and growth hormone and insulin responses to arginine infusion in children with protein-energy malnutrition before and after nutritional rehabilitation. Pediatr. Res. 20:1122-1130.

8. Flyvbjerg, A., I. Dorup, M. E. Everts, and H. Orskov. 1991. Evidence that potassium deficiency induces growth retardation through reduced circulating levels of growth hormone and insulin-like growth factor-I. Metab. Clin. Exp. 40:769775.

9. Dorup, I., A. Flyvbjerg, M. E. Everts, and T. Clausen. 1991. Role of insulin-like growth factor-I and growth hormone in growth inhibition induced by magnesium and zinc deficiencies. Br. J. Nutr. 66:505-521.

10. Oner, G., B. Bhaumick, and R. M. Bala. 1984. Effect of zinc deficiency on serum somatomedin levels and skeletal growth in young rats. Endocrinology. 114:1860-1863.

11. Straus, D. S., and C. D. Takemoto. 1991. Specific decrease in liver insulinlike growth factor-I and brain insulin-like growth factor-II gene expression in energy-restricted rats. J. Nutr. 121:1279-1286.

12. Yang, H., T. C. Cree, and D. S. Schalch. 1987. Effect of a carbohydraterestricted, calorie-reduced diet on the growth of young rats and on serum growth hormone, somatomedins, total thyroxine and triiodothyronine, free T4 index, and total corticosterone. Metab. Clin. Exp. 36:794-798.

13. Straus, D. S., and C. D. Takemoto. 1990 . Effect of dietary protein deprivation on insulin-like growth factor (IGF)-I and -II, IGF binding protein-2, and serum albumin gene expression in rat. Endocrinology. 127:1849-1860.

14. Maiter, D., T. Fliesen, L. E. Underwood, M. Maes, G. Gerard, M. L. Davenport, and J. M. Ketelslegers. 1989. Dietary protein restriction decreases insulin-like growth factor I independent of insulin and liver growth hormone binding. Endocrinology. 124:2604-2611.

15. Maiter, D., M. Maes, L. E. Underwood, T. Fliesen, G. Gerard, and J. M. Ketelslegers. 1988. Early changes in serum concentrations of somatomedin-C induced by dietary protein deprivation in rats: contributions of growth hormone receptor and post-receptor defects. J. Endocrinol. 118:113-120.

16. Moats-Staats, B. M., J. L. Brady, L. E. Underwood, and A. J. D'Ercole. 1989. Dietary protein restriction in artificially reared neonatal rats causes a reduction of insulin-like growth factor-I gene expression. Endocrinology. 125:23682374.

17. Thissen, J. P., M. L. Davenport, J. B. Pucilowska, M. V. Miles, and L. E. Underwood. 1992. Increased serum clearance and degradation of ${ }^{125}$ I-labeled IGFI in protein-restricted rats. Am. J. Physiol. 262:E406-E411.

18. Thissen, J. P., S. Triest, M. Maes, L. E. Underwood, and J. M. Ketelslegers. 1990. The decreased plasma concentrations of insulin-like growth factor-I in protein restricted rats is not due to decreased numbers of growth hormone receptors on isolated hepatocytes. J. Endocrinol. 124:159-165.

19. Thissen, J. P., L. E. Underwood, D. Maiter, M. Maes, D. R. Clemmons, and J. M. Ketelslegers. 1991. Failure of insulin-like growth factor-I (IGF-I) infusion to promote growth in protein-restricted rats despite normalization of serum IGF-I concentrations. Endocrinology. 128:885-890.

20. Thissen, J. P., S. Triest, L. E. Underwood, M. Maes, and J. M. Ketelslegers. 1990. Divergent responses of serum insulin-like growth factor-I and liver growth hormone $(\mathrm{GH})$ receptors to exogenous $\mathrm{GH}$ in protein restricted rats. Endocrinology. 126:908-913.

21. Thissen, J. P., S. Triest, B. M. Moats-Staats, L. E. Underwood, T. Mauerhoff, D. Maiter, and J. M. Ketelslegers. 1991. Evidence that pretranslational and translational defects decrease serum insulin-like growth factor-I during dietary protein restriction. Endocrinology. 129:429-435.

22. Lemozy, S., J. B. Pucilowska, and L. E. Underwood. 1994. Reduction of insulin-like growth factor I (IGF-I) in protein-restricted rats is associated with differential regulation of IGF-binding protein messenger ribonucleic acids in liver and kidney, and peptides in liver and serum. Endocrinology. 135:617-632.

23. Schalch, D. S., and T. C. Cree. 1985. Protein utilization in growth: effects of calorie deficiency on serum growth hormone, somatomedins, total thyroxine (T4) and triiodothyronine, free T4 index and total corticosterone. Endocrinology. 117:2307-2312.

24. Fliesen, T., D. Maiter, G. Gerard, L. E. Underwood, M. Maes, and J. M. Ketelslegers. 1989. Reduction of serum insulin-like growth factor-I by dietary protein restriction is age dependent. Pediatr. Res. 26:415-419.

25. Fielder, P. J., G. Thordarson, F. Talamantes, and R. G. Rosenfeld. 1990. Characterization of insulin-like growth factor binding proteins (IGFBPs) during gestation in mice: effects of hypophysectomy and an IGFBP-specific serum protease activity. Endocrinology. 127:2270-2280.

26. Giudice, L. C., E. M. Farrell, H. Pham, G. Lamson, and R. G. Rosenfeld. 1990. Insulin-like growth factor binding proteins in maternal serum throughout 
gestation and in the puerperium: effects of a pregnancy-associated serum protease activity. J. Clin. Endocrinol. \& Metab. 71:806-816.

27. Cwyfan Hughes, S. C., A. M. Cotterill, A. R. Molloy, T. B. Cassell, N. Braude, C. J. Hinds, J. A. H. Wass, and J. M. P. Holly. 1992. The induction of specific proteases for insulin-like growth factor-binding proteins following major heart surgery. J. Endocrinol. 135:135-145.

28. Davies, S. C., J. A. H. Wass, R. J. M. Ross, A. M. Cotterill, C. R Buchanan, V. J. Coulson, and J. M. P. Holly. 1991. The induction of a specific protease for insulin-like growth factor-binding protein-3 in the circulation during severe illness. J. Endocrinol. 130:469-473.

29. Armario, A., J. L. Montero, and T. Jolin. 1987. Chronic food restriction and the circadian rhythms of pituitary-adrenal hormones, growth hormone and thyroid-stimulating hormone. Ann. Nutr. \& Metab. 31:81-87.

30. Applegate, E. A., D. E. Upton, and J. S. Stern. 1984. Exercise and detraining: effect on food intake, adiposity, and lipogenesis in Osborne-Mendel rats made obese by a high-fat diet. J. Nutr. 114:447-459.

31. Carmignac, D. F., T. A. Wells, L. M. S. Carlsson, R. G. Clark, and I. C. A. F. Robinson. 1992. Growth hormone binding protein in normal and GHdeficient dwarf rats. J. Endocrinol. 135:447-457.

32. Daughaday, W. H., I. K. Mariz, and S. L. Blethen. 1980. Inhibition of access of bound somatomedin to membrane receptor and immunobinding sites: a comparison of radioreceptor and radioimmunoassay of somatomedin in native and acid-ethanol-extracted serum. J. Clin. Endocrinol. \& Metab. 51:781-788.

33. Lieberman, S. A., J. Bukar, S. A. Chen, A. C. Celniker, P. G. Compton, J. Cook, J. Albu, A. J. Periman, and A. R. Hoffman. 1992. Effects of recombinan human insulin-like growth factor-I (rhIGF-I) on total and free IGF-I concentrations, IGF-binding proteins, and glycemic response in humans. J. Clin. Endocrinol. \& Metab. 75:30-36.

34. Towbin, H., T. Staehelin, and J. Gordon. 1970. Electrophoretic transfer of proteins from polyacrylamide gels to nitrocellulose sheets: procedure and some applications. Proc. Natl. Acad. Sci. USA. 76:4350-4354.

35. Hossenlopp, P., D. Serurin, B. Gegovia-Quinson, S. Hardouin, and M. Binoux. 1986. Analysis of serum insulin-like growth factor binding proteins using Western blotting: use of the method for titration of the binding proteins and competitive binding studies. Anal. Biochem. 154:138-143.

36. Levin, N., M. Blum, and J. L. Roberts. 1989. Modulation of basal and corticotropin-releasing factor stimulated proopiomelanocortin gene expression by vasopressin in rat anterior pituitary. Endocrinology. 125:2957-2966.

37. Unterman, T. G., R. M. Vazquez, A. J. Slas, P. A. Martyn, and L. S Phillips. 1985. Nutrition and somatomedin. XIII. Usefulness of somatomedin-c in nutritional assessment. Am. J. Med. 78:228-234.

38. Kupfer, S. R., L. E. Underwood, R. C. Baxter, and D. R. Clemmons.
1993. Enhancement of the anabolic effects of growth hormone and insulin-like growth factor I by use of both agents simultaneously. J. Clin. Invest. 91:391 396.

39. Baumbach, W. R., D. L. Horner, and J. S. Logan. 1989. The growth hormone-binding protein in rat serum is an alternatively spliced form of the rat growth hormone receptor. Gene. 3:1199-1205.

40. Tiong, T. S., and A. C. Herington. 1991. Tissue distribution, characterization, and regulation of messenger ribonucleic acid for growth hormone receptor and serum binding protein in the rat. Endocrinology. 129:1628-1634.

41. Harel, Z., and G. S. Tannenbaum. 1993. Dietary protein restriction impairs both spontaneous and growth hormone-releasing factor-stimulated growth hormone release in the rat. Endocrinology. 133:1035-1043.

42. Seakins, A., and J. C. Waterlow. 1972. Effect of a low-protein diet on the incorporation of amino acids into rat serum lipoproteins. Biochem. J. 129:793795.

43. Davis, R. A., J. R. Boogaerts, R. A. Borchardt, M. Malone-McNeal, and J. Archambault-Schexnayder. 1985. Intrahepatic assembly of very low density lipoproteins. J. Biol. Chem. 26:14137-14144.

44. Pao, C. I., P. K. Farmer, S. Begovic, B. C. Billafuerte, G. Wu, D. G Robertson, and L. S. Phillips. 1993. Regulation of insulin-like growth factor-I (IGF-I) and IGF-binding protein 1 gene transcription by hormones and provision of amino acids in rat hepatocytes. Mol. Endocrinol. 7:1561-1568.

45. Donovan, S. M., L. C. Atilano, R. L. Hitz, D. M. Wilson, and R. G. Rosenfeld. 1991. Differential regulation of the insulin-like growth factors (IGFI and -II) and IGF binding proteins during malnutrition in the neonatal rat. Endocrinology. 129:149-157.

46. Spence, C. A., and F. M. Hansen-Smith. 1978. Comparison of the chemical and biochemical composition of thirteen muscles of the rat during dietary protein restriction. Br. J. Nutr. 39:647-658.

47. Tulp, O. L., and E. S. Horton. 1981. Effect of prolonged experimental protein malnutrition and of refeeding on growth, adipose tissue development and body composition in rats. $J$. Nutr. 111:1145-1156.

48. Guler, H. P., J. Zapf, E. Scheiwiller, and R. Froesch. 1988. Recombinant human insulin-like growth factor-1 stimulates growth and has distinct effects on organ size in hypophysectomized rats. Proc. Natl. Acad. Sci. USA. 85:48894893.

49. Clark, R., J. Strasser, S. McCabe, K. Robbins, and P. Jardieu. 1993. Insulin-like growth factor-I stimulation of lymphopoiesis. J. Clin. Invest. 92:540548.

50. Dallman, M. F. 1985. Control of adrenocortical growth in vivo. Endocr. Res. 10:213-242.

51. Dougherty, T. F. 1952. Effects of hormones on lymphatic tissue. Physiol. Rev. 32:379-401 